\title{
METODE “UJIAN LISAN DAN CERDAS CERMAT" UNTUK MEMOTIVASI KESEIMBANGAN HARD SKILLS DAN SOFT SKILLS SISWA SMK
}

\author{
Eko Puji Dianawati \\ SMK Negeri 1 Nanggulan \\ email: diewabid@gmail.com
}

\begin{abstract}
ABSTRAK
Tujuan penelitian ini adalah mengkaji Ujian Lisan dan Cerdas Cermat untuk memotivasi keseimbangan Hard Skills dan Soft Skill Siswa SMK. Metode penelitian dengan melakukan kajian terhadap sejumlah literatur yang dapat mendukung pendekatan analisis, meliputi: data penelitian deskriptif tentang karakteristik siswa SMK, motivasi belajar, kemampuan hard skills dan soft skills, keaktifan siswa, prestasi belajar, penggunaan ujian lisan dan cerdas cermat, metode diskusi presentasi kolaboratif, observasi dalam pembelajaran, serta teknik penilaiannya. Tuntutan guru di abad 21 harus melakukan inovasi dalam pembelajaran salah satunya menggunakan metode Ujian Lisan dan Cerdas Cermat dalam pembelajaran identifikasi ruang dan alat agar siswa lebih tertarik untuk mengenal dunia Pembibitan dan kultur jaringan di laboratorium, sehingga akhirnya siswa paham dan kompeten. Peningkatan keaktifan siswa dalam pembelajaran dapat tercapai karena siswa secara langsung mengamati/ observasi alat dimasingmasing ruang dilanjutkan membuat soal dari materi yang dipelajari untuk bahan ujian lisan dan cerdas cermat, maka dengan sedikit paksaan yang tersistem melalui teknik pembelajaran sehingga siswa terbiasa mengasah rasa ingin tahunya dengan literasi. Selain itu dengan kegiatan tersebut juga terbangunnya beberapa karakter kerja sama, disiplin, kerja keras dan menguatkan motivasi belajar secara instrinsik. Dengan metode tersebut siswa secara otomatis akan belajar berulang-ulang dan berakhir pada prestasi belajar siswa karena secara tidak langsung memotivasi siswa untuk belajar serta memunculkan kemampuan soft skills siswa.
\end{abstract}

Kata Kunci: Ujian Lisan, Cerdas Cermat, Motivasi, Hard Skills dan Soft Skills 


\section{PENDAHULUAN}

Pembibitan secara kultur jaringan merupakan mata pelajaran yang menjadi nilai lebih dari kompetensi keahlian Agribisnis Tanaman Pangan dan Hortikultura (ATPH), karena termasuk pertanian modern yang sedang digalakkan. Bahkan dengan mempelajari Pembibitan secara kultur jaringan di era jaman now, bisa menjadi salah satu tantangan untuk merubah image bahwa pertanian yang identik dengan kotor menjadi pertanian yang bersih dan rapi; petani yang tidak memiliki masa depan atau miskin berganti dengan petani yang kaya; petani yang didominasi oleh orang tua berganti petani muda yang kreatif, inovatif serta pandai melihat peluang; petani yang identik tidak gaul atau ndeso berganti menjadi petani kekinian yang cepat menyesuaikan diri dengan perkembangan globalisasi; petani yang dulu identik dengan gagap teknologi "gaptek" menjadi petani yang mendunia dengan penguasaan IT maupun smartphone untuk mengibarkan usaha dibidang pertanian sebagai ajang regenerasi petani.

Pada kegiatan pembelajaran Pembibitan dan Kultur Jaringan sebenarnya guru sudah berusaha menggunakan berbagai metode secara bervariasi mengingat penerapan Kurikulum 2013 lebih mengutamakan siswa aktif, antara lain: sistem pembelajaran dengan modul/diktat, metode diskusi interaktif, presentasi kolaboratif, tanya jawab, penerapan pembelajaran teman sebaya, penugasan (media games maupun kuiz), observasi / pengamatan langsung maupun praktek, agar siswa lebih tertarik dan aktif dalam mengikuti pelajaran dikelas, maupun di laboratorium bahkan bisa tergugah untuk bereksperimen.

Tantangan guru saat ini harus pandai mengemas metode pembelajaran yang semenarik dan serileks mungkin. Bahkan tugas guru sekarang ini bukanlah "mengajar", tetapi "membelajarkan. Itu berarti bahwa kegiatan pembelajaran harus berpusat pada siswa, Guru dituntut mampu mewujudkan pendidikan yang perfect yaitu pendidikan yang tidak hanya mengantarkan siswa memperoleh nilai yang tinggi (ulangan harian/UH, ujian nasional) tetapi lebih kepada pendidikan karakter 
yang dapat membentuk kepribadian siswa secara utuh dengan memperhatikan faktor spiritual, sosial, emosional dan intelektual.

Ada 3 hal yang menentukan untuk menjadi guru terbaik yang dapat memberikan pembelajaran optimal bagi siswanya sehingga dihasilkan lulusan berkualitas dan paripurna, yaitu: (1) guru sebagai fasilitator, memfasilitasi dengan memberi porsi yang besar kepada siswa dalam proses pembelajaran sehingga pemikiran siswa dapat tumbuh kembang dengan optimal; (2) guru sebagai katalisator, akan terus memantik kemampuan siswa termasuk bakatnya, terutama pada siswa yang lamban dalam memahami pelajaran; dan (3) guru harus dapat menyesuaikan gaya mengajarnya dengan gaya belajar siswa, apabila proses teaching style dengan learning style sesuai maka akan muncul kondisi sebenarnya dimana tidak ada pelajaran yang sulit dan semua siswa dapat menerima pelajaran dari guru.

Pembelajaran kompetensi Pembibitan dan kultur jaringan, membutuhkan motivasi yang luar biasa untuk mensukseskan kompetensi tersebut, agar menjadi sisi lebih dari hal yang dipelajarinya. Sesuai dengan Slogannya SMK "BISAHEBAT, Siap Kerja, Santun, Mandiri dan Kreatif”. Beberapa tantangan yang dihadapi adalah: 1) Kegiatan pembelajaran banyak dilakukan di laboratorium yang membutuhkan kedisiplinan, ketelitian, kesabaran dan keterampilan, 2) Dibutuhkan motivasi yang tinggi untuk bekerja sesuai SOP, 3) Jenis alat yang digunakan dalam laboratorium sangatlah spesifik dimasing-masing ruang sehingga dibutuhkan perjuangan untuk memahaminya, 4) Diharapkan memiliki rasa tertarik pada kegiatan eksperimen atau penelitian.

Berdasarkan uraian diatas maka guru harus melakukan inovasi salah satunya menggunakan metode Ujian Lisan dan Cerdas Cermat dalam pembelajaran identifikasi ruang dan alat agar siswa lebih tertarik untuk mengenal dunia Pembibitan dan kultur jaringan di laboratorium, sehingga akhirnya siswa paham dan kompeten. Terbukti dengan meningkatnya keaktifan siswa dalam pembelajaran karena siswa secara langsung mengamati/ observasi alat dimasing-masing ruang dan berakhir pada prestasi belajar siswa karena secara tidak langsung memotivasi siswa untuk belajar serta memunculkan kemampuan soft skills. 


\section{METODE}

Penelitian ini di awali dengan melakukan kajian terhadap sejumlah literatur yang dapat mendukung pendekatan analisis, meliputi: data penelitian deskriptif tentang karakteristik siswa SMK, motivasi belajar, kemampuan hard skills dan soft skills, keaktifan siswa, prestasi belajar, penggunaan ujian lisan dan cerdas cermat, metode diskusi presentasi kolaboratif, observasi dalam pembelajaran, serta teknik penilaiannya. Sumber kajian yang digunakan berupa buku referensi, maupun website yang diakses melalui internet. Penelitian deskriptif merupakan penelitian yang dimaksudkan untuk mengumpulkan informasi mengenai status suatu gejala yang ada, yaitu keadaan gejala menurut apa adanya pada saat penelitian itu dilakukan (Arikunto, 2013). 


\section{HASIL DAN PEMBAHASAN}

\section{Karakteristik Siswa SMK}

Karakteristik pendidikan kejuruan menurut (Djohar, 2007) adalah: a) Pendidikan kejuruan merupakan pendidikan yang memiliki sifat menyiapkan penyediaan tenaga kerja. Oleh karena itu orientasi pendidikannya tertuju pada lulusan yang dapat dipasarkan di pasar kerja, b) Pengalaman belajar mencakup ranah afektif, kognitif, dan psikomotorik yang diaplikasikan melalui proses belajar mengajar, maupun situasi kerja yang sebenarnya, c) Keberhasilan pendidikan kejuruan diukur dari keberhasilan siswa di sekolah (in-school success), dan keberhasilan siswa di luar sekolah (out-of school success), d) Bengkel kerja dan laboratorium merupakan kelengkapan utama dalam pendidikan kejuruan, untuk mewujudkan situasi belajar yang mencerminkan situasi dunia kerja secara realistis dan edukatif.

Fenomena yang terjadi, antara dunia pendidikan dan perkembangan masyarakat tidak match dan terjadi kesenjangan cukup signifikan. Indikatornya adalah, lulusan lembaga pendidikan belum siap pakai. Dunia industri pun akhirnya meninggalkan sekolah karena tidak ada link untuk membangun relasi. Terbukti perusahaan besar masih banyak yang enggan menerima siswa SMK untuk melaksanakan Praktik Kerja Lapangan (PKL), karena diasumsikan tidak memberikan kontribusi yang berarti bagi perusahaan tersebut.

Peserta didik pada Sekolah Menengah Kejuruan (SMK) tentunya berkeinginan memiliki kemampuan vokatif. Harapan mereka setelah lulus dapat langsung bekerja. Namun akhir-akhir ini banyak yang melanjutkan ke perguruan tinggi dengan mengambil bidang profesional atau bidang akademik. Usia peserta didik SMK secara umum pada rentang 15/16 - 18/19 tahun, atau berada pada masa remaja yang sedang berproses untuk mencari identitas diri ini juga sering menimbulkan masalah pada diri remaja.

Pada umumnya siswa SMK belum bisa bertanggung jawab akan masa depannya dan sekolah hanya memenuhi status sebagai pelajar namun esensi tujuan masa depannya belum terpola dalam cita-cita setelah lulus SMK. Bisa kita lihat saat pendaftaran peserta didik baru (PPDB), siswa yang memilih sekolah SMK seharusnya paham betul akan jurusan yang diambil, namun kenyataannya dan rata- 
rata, karena nilai mereka mengkategorikan pilihan jurusannya, belum pada minat yang berakhir pada kompetensi yang ingin dicapainya. Apalagi dengan PPDB online, banyak calon siswa kurang memahami jurusan yang diambilnya. Bahkan yang terjadi siswa tidak paham akibatnya salah memilih jurusan dan saat pengumuman penerimaan, siswa tersebut tidak melaksanakan daftar ulang, sehingga banyak sekolah kurang terpenuhi jumlah siswanya.

\section{Motivasi Belajar}

Istilah motivasi berasal dari kata motif yang artinya kekuatan yang terdapat dalam diri individu, yang menyebabkan individu tersebut bertindak atau berbuat. Motif tidak dapat diamati secara langsung tetapi dapat diinterpretasikan dalam tingkah lakunya, berupa rangsangan, dorongan, atau pembangkit tenaga munculnya suatu tingkah laku tertentu (Adi, 1994).

Motivasi belajar merupakan bagian dari motivasi secara umum. Dalam kegiatan belajar mengajar dikenal adanya motivasi belajar yaitu motivasi yang ada dalam dunia pendidikan atau motivasi yang dimiliki siswa (Nuraeni, 2013). Sedangkan menurut (Mulyadi et al., 2016) motivasi belajar adalah membangkitkan dan memberikan arah dorongan yang menyebabkan individu melakukan perbuatan belajar. Dari beberapa pendapat tersebut penulis menyimpulkan motivasi belajar memegang peranan penting dalam memberikan gairah atau semangat dalam belajar, sehingga siswa yang bermotivasi kuat untuk melakukan kegiatan belajar.

Dari sudut sumber yang menimbulkannya, motivasi dibedakan menjadi dua macam yaitu motivasi intrinsik dan motivasi ekstrinsik (Uno, 2014). Motivasi intrinsik timbul tidak memerlukan rangsangan dari luar kerena memang telah ada dalam diri individu sendiri, misalnya: siswa terbiasa belajar secara rutin karena menyadari akan kemampuannya memahami materi misalnya perlu membaca beberapa kali kemudian berusaha menulis kembali dan akhirnya memahaminya. Atau memang memiliki rasa ingin tahu yang besar akhirnya belajar menjadi suatu kebutuhan. Motivasi intrinsik dikenal juga dengan motivasi bawaan. Sedangkan motivasi ekstrinsik timbul karena adanya rangsangan dari luar individu (adanya ajakan, suruhan atau paksaan dari orang lain), misalnya:siswa mau belajar karena ada ujian lisan dan cerdas cermat sehingga termotivasi untuk belajar karena 
perasaan malu jika tidak bisa menjawab atau menyadari kompetisi untuk mencapai nilai yang maksimal (diatas KKM: 75). Motivasi intrinsik umumnya lebih kuat dari motivasi ekstrinsik. Oleh karena itu, pendidikan sebaiknya berusaha menimbulkan motivasi intrinsik.

Motivasi ekstrinsik diperlukan juga dalam kegiatan belajar karena tidak semua siswa memiliki motivasi intrinsik yang kuat untuk belajar. Siswa yang memiliki motivasi dilihat dari ciri-ciri yang diamati pada saat siswa tersebut mengikuti pelajaran. misalnya: 1) Tekun menghadapi tugas (dapat bekerja terus menerus dalam waktu yang lama, tidak berhenti sebelum selesai), 2) Ulet menghadapi kesulitan (tidak lekas putus asa), 3) Menunjukkan minat terhadap aneka masalah, 4) Lebih senang bekerja mandiri, 5) Cepat bosan pada tugas rutin, 6) Dapat mempertahankan pendapatnya,7) Senang mencari dan memecahkan masalah (AM, 2007).

\section{Kemampuan Hard Skills dan Soft Skills}

Hard skills merupakan penguasaan ilmu pengetahuan, teknologi dan keterampilan teknis yang berhubungan dengan bidang ilmunya dan lebih beriorentasi mengembangkan intelligence quotient (IQ) (Dany, 2012).

Soft skills adalah sebuah istilah dalam sosiologi yang berkaitan dengan kecerdasan emosional, sifat kepribadian, ketrampilan sosial, komunikasi, berbahasa, kebiasaan pribadi, keramahan, dan optimisme yang mencirikan kemampuan seseorang dalam berhubungan dengan orang lain. Soft skills merupakan kecerdasan emosional dan sosial EQ (Emotional Intelligence Quotient) yang sangat penting untuk melengkapi hard skills atau kecerdasan intelektual (Intelligence Quotient) (Dany, 2012).

Dari pendapat diatas pengertian soft skills merupakan keterampilan seseorang dalam berhubungan dengan orang lain (interpersonal skills) dan keterampilan mengatur dirinya sendiri (intrapersonal skills) yang mempu mengembangkan untuk kerja secara maksimal.

Selama ini peserta didik di SMK lebih banyak mendapatkan hard skills dan lupa terhadap soft skills-nya, sehingga kelemahan lulusan SMK dalam mengisi peluang kerja pada umumnya adalah masalah personal skills. Kemampuan soft skills bisa diasah dan ditingkatkan seiring dengan pengalaman belajar, sehingga 
perlu berfikir dan bertindak dari fokus pada hard skills saja menjadi mensinergikan antara hard skills dengan soft skills.

Anak SMK yang diharapkan dari memiliki keseimbangan kemampuan hard skills dan soft skill adalah untuk membekalinya di dunia kerja, mengingat real di lapangan dalam pekerjaan team work dibutuhkan kemampuan untuk berkomunikasi. Dan yang jauh lebih penting adalah pendidikan karakter seperti jujur, kerja sama, santun, sabar, toleransi, percaya diri, mandiri, kreatif, semangat kerja keras, punya inisiatif dan inovasi. Sehingga jika lulusan SMK memiliki kemampuan itu semua (hard skills dan soft skills) maka dia menjadi tenaga yang handal baik secara kompetensi maupun secara sosial kepribadian. Sehingga secara teknis tidak kalah dengan lulusan sarjana, artinya lulusan SMK pun bisa berkarier. Seperti alumni SMK Negeri 1 Nanggulan yang telah bekerja di PT Quick dan ini nyata terjadi siswa itu dulu kami didik dikelas dengan kemampuan normal, namun memiliki kemampuan sosial dan karakter yang bagus dan kini kembali hadir ke SMK Negeri 1 Nanggulan sebagai pemateri diklat Alat dan Mesin Traktor yang diadakan sebagai bentuk pelayanan kepada konsumen dalam acara diklat guru karena SMK membeli produk mesin panen Harvester QH-11 dan aneka jenis traktor seperti traktor roda 4, traktor tangan, traktor cakar bajak untuk membuat bedengan dan traktor pencacah tanah. Ini kejadian yang luar biasa membikin kami bangga memiliki alumni yang sukses sebagai pemateri diklat alsintan ke berbagai pulau di Indonesia.

\section{Keaktifan Siswa}

Guru pengampu mata pelajaran kejuruan/produktif mempunyai peran yang stategis dalam menghasilkan lulusan SMK yang kompeten dan siap kerja. E. Mulyasa dalam (Ilham, 2009) mengatakan bahwa: Pembelajaran dikatakan berhasil dan berkualitas apabila seluruhnya atau setidak-tidaknya sebagian besar (75\%) peserta didik terlibat secara aktif, baik fisik, mental maupun sosial dalam proses pembelajaran, di samping menunjukkan kegairahan belajar yang tinggi, semangat belajar yang besar, dan rasa percaya pada diri sendiri.

Beberapa bentuk upaya yang dapat dilakukan guru dalam mengembangkan keaktifan belajar siswa di antaranya dengan meningkatkan minat siswa, 
membangkitkan motivasi siswa, menerapkan prinsip individualitas siswa, serta menggunakan media dalam pembelajaran.Keaktifan siswa dalam (Quintana, 2016) dapat diklasifikasikan sebagai berikut: a) Keaktifan visual, misalnya kegiatan siswa saat melaksanakan observasi ruang atau alat-alat laboratorium dan mengamati eksperimen yang dilakukan oleh guru atau siswa lain, b) Keaktifan lisan (oral), misalnya kegiatan siswa saat mengemukakan suatu fakta atau prinsip yang berhubungan dengan materi pembelajaran, mengajukan pertanyaan kepada guru jika belum mengerti atau bertanya kepada siswa lain saat mempresentasikan gagasannya di depan kelas, memberi saran maupun mengemukakan pendapat saat diskusi kelas berlangsung, c) Keaktifan mendengarkan, d) Keaktifan menulis,, e) Keaktifan menggambar, f) Keaktifan motorik, g) Keaktifan mental, h) Keaktifan emosional,

\section{Prestasi Belajar}

(Winkel, 2004) mengatakan bahwa belajar adalah suatu aktivitas mental/psikis yang berlangsung dalam interaksi aktif dengan lingkungannya yang menghasilkan perubahan-perubahan, pengetahuan, pemahaman, keterampilan, dan nilai sikap, serta perubahan itu bersifat secara relatif konstan dan tetap. (Sudjana, 2006) mengatakan bahwa belajar merupakan suatu proses yang ditandai dengan adanya perubahan yang ada dalam diri seseorang, perubahan sebagai hasil, dan belajar dapat ditunjukkan dalam berbagai bentuk, seperti perubahan pengetahuan, perubahan sikap dan tingkah laku.

Sesuai dengan pendapat (Suryabrata, 2015) bahwa guru jangan berdiri di depan siswa, tetapi berdirilah disamping siswa; jangan menunjukkan otoritas (kekuasaan), tetapi tunjukkanlah simpati, usahakan mendapatkan kepercayaan dari siswa, dan selanjutnya berilah bimbingan. Dalam metode mengajar, guru paham betul karakter siswa/peserta didik dimana dengan pembelajaran yang menyenangkan dapat memberikan efek luar biasa terhadap kuatnya otak mempertahankan pengetahuan (Knowledge) yang disimpan dalam memorinya (Dianawati, 2013).

Tiga macam Prestasi belajar, yakni (a) keterampilan dan kebiasaan, (b) pengetahuan dan pengertian, (c) sikap dan cita-cita. Ranah kognitif berkenaan 
dengan prestasi belajar intelektual yang terdiri dari enam aspek, yakni pengetahuan (Knowledge) atau ingatan, pemahaman (Comprehension), aplikasi, analisis, sintesis, dan evaluasi. Kedua aspek pertama disebut kognitif tingkat rendah dan keempat aspek berikutnya termasuk kognitif tingkat tinggi. Ranah afektif berkenaan dengan sikap yang terdiri dari lima aspek, yakni penerimaan jawaban atau reaksi, penilaian, organisasi, dan internalisasi. Ranah psikomotorik berkenaan dengan hasil belajar keterampilan dan kemampuan bertindak. Ada enam aspek ranah psikomotorik, yakni gerakan refleks, keterampilan gerakan dasar, kemampuan perseptual, keharmonisan atau ketetapan, gerakan keterampilan kompleks, dan gerakan ekspresif dan interpretative (Mulyasa, 2002)

Sesuai pendapat (Dianawati, 2013) bahwa keberhasilan belajar siswa pada dasarnya dipengaruhi oleh tiga peta belajar siswa yaitu daya serap, daya simpan (save) dan kemampuan menyampaikan atau mengeluarkan kembali (reproduksi).

Dari beberapa pendapat dapat disimpulkan bahwa prestasi belajar adalah kemampuan siswa menyampaikan pemahamannya terhadap materi yang diperoleh baik berupa aspek pengetahuan, sikap maupun keterampilannya.

\section{Penggunaan Metode Ujian Lisan dan Cerdas Cermat}

(Hamalik, 2008) mengemukakan bahwa penilaian adalah suatu proses berkelanjutan tentang pengumpulan dan penafsiran informasi untuk menilai keputusan-keputusan yang dibuat dalam merancang suatu sistem pengajaran. Sedangkan (Arikunto, 2006) mengemukakan bahwa penilaian dalam pendidikan adalah kegiatan menilai yang terjadi dalam kegiatan pendidikan atau sekolah Berdasarkan penjelasan di atas, dapat disimpulkan bahwa penilaian dapat diartikan sebagai suatu kegiatan tentang hasil pembelajaran dari masing-masing siswa, serta keberhasilan siswa dalam kelas secara keseluruhan, selain itu juga merupakan indikator keberhasilan guru dalam proses pembelajaran.

Sesuai dengan pendapat (Mudyahardjo, 2004) bahwa peranan guru dalam penyelenggaraan bentuk-bentuk kegiatan pendidikan adalah sentral, selain itu bentuk kegiatan pendidikan berorientasi pendidikan yang terprogram dalam bentuk sebuah kurikulum. Sehingga dapat dikatakan bahwa guru mengendalikan penyelenggaraan bentuk-bentuk kegiatan pendidikan sejak dari perencanaan sampai dengan penilaian pendidikan. 
Penggunaan metode Ujian Lisan dan Cerdas Cermat dapat diidentifikasi melalui pengelompokkan metode diskusi presentasi kolaboratif, observasi yang diperkaya dan berorientasi kepada keaktifan siswa dalam pembelajaran, pemberian tugas menyusun soal sekaligus melakukan penyelesaian soal yang mereka buat sendiri. Metode ini merupakan bentuk ikhtiar guru dalam kegiatan belajar mengajar dengan membagikan lembar diskusi secara individu pada masing-masing kelompok dengan topik yang berbeda untuk didiskusikan dengan melihat ruang dan alat laboratorium secara langsung (realia) dan akan dipresentasikan untuk saling bertukar informasi sehingga harapannya semua siswa aktif mempelajari semua materi diskusi, aktif bertanya mana maupun memberikan tanggapan jika kontens dari pembahasan kurang tepat. Artinya belajar dengan teman sebaya jauh lebih rileks dan leluasa dalam belajar. Kemudian mengadakan ujian lisan dengan observasi alat secara langsung dengan instrumen penskoran yang jelas sehingga meminimalkan subyektivitas dan menjaga azas adil serta terbuka dalam ujian lisan dan cerdas cermat. Setelah tahap ujian lisan dipadu dengan observasi alat selesai, siswa diajak untuk berkompetisi dalam ujian lisan dalam kegiatan cerdas cermat (soal dari siswa untuk siswa). Dengan demikian siswa secara tidak langsung diajak untuk pembiasaan belajar secara kontinue dengan melatih diri membuat soal dan menyelesaikan sendiri, siswa semakin kompeten membuat pola belajar aktif, dalam rangka menyiapkan siswa sukses Ujian Kejuruan dan sukses dalam pembentukan karakter berkaitan akan memasuki dunia kerja dengan membiasakan selalu memiliki rasa percaya diri, bekerja keras, mampu berkomunikasi dengan bahasa yang santun, bekerja sama /team work, terbiasa dengan tanggung jawab mengemban tugas sesuai instruksi dan delegasi, serta memiliki inisiatif.

Contoh instrumen penskoran penilaian ujian lisan

\begin{tabular}{|c|c|c|c|c|c|c|c|c|}
\hline \multirow{2}{*}{ No. } & \multirow{2}{*}{ Nama Siswa } & \multicolumn{6}{|c|}{ Ujian Lisan dipadu Observasi Alat } & \multirow[t]{2}{*}{ Nilai } \\
\hline & & $\begin{array}{c}\text { Jenis } \\
\text { alat } \\
\end{array}$ & Fungsi & Ruang & SOP & K3 & $\begin{array}{l}\text { Total } \\
\text { Skor } \\
\end{array}$ & \\
\hline & & & & & & & & \\
\hline & & & & & & & & \\
\hline
\end{tabular}

Skor 4 : Bilamana mendiskripsikan 5 (jenis alat, fungsi, ruang, SOP dan K3)

Skor 3 : Bilamana mendiskripsikan 4 (jenis alat, fungsi, ruang, SOP dan K3) 
Skor 2 : Bilamana mendiskripsikan 3/2 (jenis alat, fungsi, ruang, SOP dan K3)

Skor 1 : Bilamana mendiskripsikan 1 (jenis alat, fungsi, ruang, SOP dan K3)

Nilai $=$ Jumlah skor yang diperoleh $\times 100$ 20 (skor maksimal)

Contoh instrumen penskoran penilaian cerdas cermat

\begin{tabular}{|l|c|c|c|c|c|c|}
\hline No. & Nama Siswa & \multicolumn{2}{|c|}{ Kemampuan Menjawab Ujian Cerdas Cermat } & Skor & Nilai \\
\cline { 3 - 5 } & & Soal wajib & Soal Lemparan & Soal Rebutan & Total & \\
\cline { 3 - 5 } & & Pilihan Ganda & Uraian Singkat & Esay & \\
\cline { 3 - 5 } & & Skor max: 5 & Skor max: 9 & Skor max: 18 & \\
\hline & & & & & & \\
\hline & & & & & & \\
\hline
\end{tabular}

Masing siswa mendapat: 5 soal wajib dan 3 soal lemparan

Skor untuk soal wajib dan lemparan : $\quad$ Jika benar $=1$ dan jika salah $=0$

Skor untuk soal rebutan $\quad$ : Jika benar $=3$, jika sebagian besar benar $=2$, jika sebagian kecil benar $=$

1 , jika salah $=0,5$

\begin{tabular}{|l|l|l|c|}
\hline Jumlah skor total & Nilai & Jumlah Skor Total & Nilai \\
\hline$>20$ & 100 & $13-14$ & 80 \\
\hline $19-20$ & 95 & $11-12$ & 78 \\
\hline $17-18$ & 90 & 10 & 75 \\
\hline $15-16$ & 85 & $<10$ & Tidak KKM \\
\hline
\end{tabular}


Contoh instrumen soft skills tentang kemampuan percaya diri, komunikasi, managemen emosi selama ujian lisan

\begin{tabular}{|c|c|c|c|c|c|c|c|c|c|c|c|c|c|}
\hline \multirow[t]{3}{*}{ No. } & \multirow{3}{*}{$\begin{array}{l}\text { Nama } \\
\text { Siswa }\end{array}$} & \multicolumn{12}{|c|}{ Pengamatan kemampuan soft skills } \\
\hline & & \multicolumn{2}{|c|}{ Tenang } & \multicolumn{2}{|c|}{$\begin{array}{c}\text { Lancar } \\
\text { menjawab }\end{array}$} & \multicolumn{2}{|c|}{$\begin{array}{l}\text { Perhatian/ } \\
\text { Fokus }\end{array}$} & \multicolumn{2}{|c|}{$\begin{array}{r}\text { Tatapan } \\
\text { kedepan }\end{array}$} & \multicolumn{2}{|c|}{$\begin{array}{c}\text { Bahasa } \\
\text { santun \& } \\
\text { runtut }\end{array}$} & \multicolumn{2}{|c|}{$\begin{array}{c}\text { Waktu @ < } \\
5 \text { ‘ }\end{array}$} \\
\hline & & $\mathrm{Ya}$ & Tdk & $\mathrm{Ya}$ & $\mathrm{Tdk}$ & $\mathrm{Ya}$ & Tdk & $\mathrm{Ya}$ & $\mathrm{Tdk}$ & $\mathrm{Ya}$ & Tdk & $\mathrm{Ya}$ & Tdk \\
\hline & & & & & & & & & & & & & \\
\hline & & & & & & & & & & & & & \\
\hline
\end{tabular}

\section{SIMPULAN}

Secara singkat kelebihan Ujian Lisan dan Cerdas Cermat adalah dapat memotivasi dalam pembiasaan belajar dengan aktif membaca untuk menemukan hasil pembahasan, melatih membuat soal dan menyelesaikannya, melatih rasa percaya diri akan kesiapan menempuh ujian kejuruan dan mendorong siswa untuk mengeluarkan kembali hasil pemahamannya secara lisan agar terlatih untuk menjadi pribadi yang kreatif dan berinovasi mengembangkan dan mengaktualisasikan diri di masyarakat maupun di dunia kerja nantinya.

Penilaian ujian lisan dan cerdas cermat dilaksanakan dengan menggunakan prinsip terbuka, artinya model penilaiannya diinformasikan secara terbuka kepada siswa. Selain itu cara ujian lisan menggunakan sistem tes lisan berpedoman tertulis. Model penilaian yang dimaksud antara lain meliputi bobot skor masing-masing soal, kejelasan maksud soal, dan soal dari siswa untuk siswa. Bahkan siswa bisa menghitung sendiri perolehan nilai yang diperolehnya.

Guru sebagai pengelola pembelajaran mengadakan penilaian dengan maksud melihat apakah usaha yang dilakukan melalui pembelajaran sudah mencapai tujuan yaitu pembelajaran yang tidak membosankan, dapat membiasakan siswa belajar latihan soal dengan membuat soal sendiri maupun membiasakan keseimbangan kemampuan hard skills dan soft skills. Atribut soft skills diurut berdasarkan prioritas kepentingan di dunia kerja, yaitu: (1) inisiatif, (2) etika/integritas, (3) berfikir kritis, (4). kemauan belajar, (5) komitmen, (6) motivasi, (7) bersemangat, (8) dapat diandalkan, (9) komunikasi lisan, (10) kreatif, (11) kemampuan analitis, (12) dapat mengatasi stres, (13) manajemen diri, (14) menyelesaikan persoalan, (15) dapat meringkas, (16) berkoperasi, (17) fleksibel, (18) kerja dalam tim, (19) mandiri, (20) mendengarkan, (21) tangguh, (22) berargumentasi logis, (23) manajemen waktu 


\section{DAFTAR PUSTAKA}

Adi, I. R. (1994). Psikologi, pekerjaan sosial dan ilmu kesejahteraan sosial : dasardasar pemikiran. Raja Grafindo Persada.

AM, S. (2007). Interaksi dan Motivasi Belajar Mengajar. Raja Grafindo Persada.

Arikunto, S. (2006). Metode Penelitian Kualitatif. Bumi Aksara.

Arikunto, S. (2013). Manajemen Penelitian. Rineka Cipta.

Dany. (2012). Apa it soft skills? http://muhammaddany.blogspot.com/2012/03/softskill-dan-hard-skill.html

Dianawati, E. P. (2013). Penggunaan Media Word Squaredalam Memotivasi Belajar Siswa Smk. Jurnal Ilmiah Guru Caraka Olah Pikir Edukatif, O(1).

Djohar, A. (2007). Pendidikan Teknologi dan Kejuruan. Dalam Ilmu Dan Aplikasi Pendidikan, 1285, 1300. https://scholar.google.co.id/citations?view_op=view_citation\&hl=en\&user=n zU41JgAAAAJ\&citation_for_view=nzU41JgAAAAJ:u5HHmVD_uO8C

Hamalik, O. (2008). Perencanaan Pengajaran Berdasarkan Pendekatan Sistem (7th ed.). Bumi Aksara. https://www.bukalapak.com/p/hobikoleksi/buku/sosial/9i4rgx-jual-perencanaan-pengajaran-berdasarkanpendekatan-sistem-oemar-hamalik-buku-pendidikan-b65

Ilham. (2009). Mengembangkan Keaktifan Belajar Siswa. Abangilham's Blog. https://abangilham.wordpress.com/2009/03/31/pentingnya-upaya-gurudalam-mengembangkan-keaktifan-belajar-siswa/

Mudyahardjo, R. (2004). Filsafat Ilmu Pendidikan. Remaja Rosdakarya.

Mulyadi, S., Basuki, H., \& Rahardjo, W. (2016). Psikologi Pendidikan: dengan Pendekatan Teori-teori Baru dalam Psikologi. Rajawali Pers. https://www.belbuk.com/psikologi-pendidikan-dengan-pendekatanteoriteori-baru-dalam-psikologi-p-55739.html

Mulyasa, E. (2002). Kurikulum Berbasis kompetensi (1st ed.). Rosdakarya. http://library.fip.uny.ac.id/opac/index.php?p=show_detail\&id=2510

Nuraeni, N. (2013). Pengertian Motivasi, Fungsi Serta Jenis-Jenis Motivasi Belajar. http://neyynuraeni.blogspot.com/2013/02/pengertian-motivasifungsi-serta-jenis.html

Quintana, S. (2016). Keaktifan Belajar Siswa.

Sudjana, N. (2006). Penilaian hasil proses belajar mengajar. Remaja Rosdakarya. 
Suryabrata, S. (2015). Psikologi Pendidikan. Rajawali Pers.

Uno, H. B. (2014). Teori Motivasi dan Pengukurannya: Analisis di Bidang Pendidikan. Bumi Aksara.

Winkel, W. (2004). Psikologi Pengajaran. MEDIA ABADI. 